\title{
Hjerterisiko ved AD/HD-behandling hos barn
}

I 2006 gikk FDA (Food and Drug Administration) ut med en advarsel på grunn av bekymring for den økende bruken av sentralstimulerende medikamenter til behandling av $\mathrm{AD} / \mathrm{HD}$ og mulig risiko for kardiovaskulære bivirkninger (1). Advarselen ble trukket tilbake kort tid etter fordi man ikke kunne påvise økt risiko hos barn under 18 år. Men mange, både pasienter og behandlere, ble engstelige for slike bivirkninger, og det førte til at det ble innført en rekke forholdsregler før oppstart av behandling med sentralstimulerende midler, blant annet EKG-utredning. Advarselen førte også til at det ble initiert en rekke studier der man skulle undersøke risikoen for kardiovaskulære bivirkninger.

$\mathrm{AD} / \mathrm{HD}$ er en tilstand som karakteriseres ved konsentrasjonssvikt, uro, rastløshet og impulsivitet. Symptomene debuterer oftest i barndommen og kan medføre betydelig funksjonsnedsettelse (2). Når symptomer gir funksjonsnedsettelse, vil det som oftest være nødvendig å starte medikamentell behandling, sammen med støttende tiltak som spesialpedagogisk innsats og foreldreveiledning i atferdsmodifisering. I Norge brukes hovedsakelig de sentralstimulerende legemidlene metylfenidat og ulike amfetaminderivater samt atomoksetin, som er et sentralvirkende sympatikomimetikum. Man har etter hvert flere tiårs erfaring med behandling av $\mathrm{AD} / \mathrm{HD}$ med metylfenidat, som har god effekt på kjernesymptomer, skoleprestasjoner og sosial fungering (2).

Gir medikamentell behandling økt risiko for kardiovaskulære tilstander hos barn? Ansgar Berg og medarbeidere har i dette nummer av Tidsskriftet en grundig litteraturgjennomgang, og de finner ikke dokumentasjon på en økning i alvorlige kardiovaskulære hendelser hos barn med AD/HD som har fătt medikamentell behandling (3). Forekomsten av alvorlige kardiovaskulære hendelser, som plutselig hjertedød, slag eller alvorlige arytmier, er svært lav i barnepopulasjonen. Det kreves derfor store studiepopulasjoner for å kunne utforske en mulig sammenheng. I 2012 publiserte Winterstein og medarbeidere en kohortstudie av barn som ble behandlet for $\mathrm{AD} / \mathrm{HD}$, rekruttert fra en populasjon på 24 millioner barn og unge i alderen 0-18 år (en firedel av barnepopulasjonen i USA) (4). De kunne ikke påvise at bruk av AD/HD-medisiner var assosiert med $ø k t$ risiko for alvorlige kardiovaskulære hendelser. De fant heller ingen økt risiko i subgruppen av barn med kjent hjertesykdom og $\mathrm{AD} / \mathrm{HD}$. Det er kjent at de sentralstimulerende legemidlene gir en moderat økning i puls og blodtrykk (5). Hos dem som i utgangspunktet har grenseforhøyede verdier, kan dette bety behov for behandling og mulig risiko for fremtidig hjerte- og karsykdom.

Gitt denne kunnskapen - hvor mye bør vi utrede disse barna før vi starter behandling? I Norge har det vært vanlig å ta EKG i tillegg til den generelle risikovurderingen, som består av anamnese med tanke på arvelig belastning og symptomer og klinisk undersøkelse, inkludert puls og blodtrykk. En EKG-undersøkelse er billig og enkelt å utføre og fristende å ty til for sikkerhets skyld. Berg og medarbeidere viser til økt antall henvisninger med bestilling om vurdering av mulig patologisk EKG hos pasienter der sentralstimulerende medikamentell behandling vurderes. Dette er også vår erfaring. Mahle og medarbeidere fant 8,1\% patologiske EKG-undersøkelser (119 tilfeller av 1 470) ved første screening i en kohort av barn hvor det var planlagt oppstart av medikamentell behandling (6). Ved ny vurdering hos barnekardiolog ble $35 \%$ av disse vurdert som falskt positive. Ytterligere utredning av disse avdekket kun én som hadde en tilstand som skulle tilsi ekstra forsiktighet ved bruk av medikamentene.
I Norge utføres EKG-undersøkelse hos fastlegen. Pediatrisk EKG skiller seg fra EKG hos voksne, og mange som ikke jobber med barnekardiologi, har ikke erfaring i å tolke disse. Feil plassering av elektroder eller feil i den initiale fortolkningen er, etter vår vurdering, årsaken til mange henvisninger pga. mistenkt patologisk EKG. Gitt det nåværende kunnskapsgrunnlaget innebærer en slik henvisning unødvendig frykt for sykdom, unødvendige undersøkelser, utsatt behandlingsstart og fravær fra skole og arbeid.

Berg og medarbeidere presenterer en algoritme som ivaretar tilstrekkelig og riktig kardiologisk utredning og oppfølging av barn med AD/HD som trenger medikamentell behandling. Denne er bygd på oppdatert forskning på feltet og harmonerer godt med gjeldende norske (2) og europeiske (7) retningslinjer. Ved hjelp av målrettet risikoanamnese og klinisk undersøkelse identifiseres de barna som bør vurderes av barnekardiolog før oppstart. Hos dem som ikke har noen bakgrunnsrisiko, gir EKG lite tilleggsinformasjon, og undersøkelsen er derfor ikke nødvendig. Barn med hjerte- og karsykdom eller med familiær risiko for dette har også AD/HD og trenger behandling. Hos disse er det nødvendig med utredning for å avdekke om behandlingen kan gjennomføres, og de trenger ekstra oppfølging underveis.

$\mathrm{Vi}$ vet fortsatt for lite om risikoen ved lang tids medikamentell $\mathrm{AD} / \mathrm{HD}$-behandling. Men det kunnskapsgrunnlaget vi har nå, tilsier at dette er trygt for de aller fleste hvis de får god oppfølging. Det gjelder også dem med underliggende sykdom. I dagens samfunn er man i stor grad blitt så redd for å overse noe at man garderer seg med ekstra undersøkelser. Følges retningslinjene, kan vi på poliklinikkene få frigjort tid til å ta oss av de pasientene som trenger det.

\section{Christine Vaksdal Nilsen}

christine.vaksdal.nilsen@helse-mr.no

Christine Vaksdal Nilsen (f. 1974) er spesialist i barnesykdommer, med interessefelt barnekardiologi og neonatologi. Hun er seksjonsoverlege ved Barne- og ungdomsavdelingen ved Ålesund sjukehus.

Forfatter har fylt ut ICMJE-skjemaet og oppgir ingen interessekonflikter.

\section{Litteratur}

1. Gorman RL. Pediatric drug labeling: FDA panel recommends black box warning on ADHD stimulant medications. AAP News 2006; 27: 16.

2. Veileder i diagnostikk og behandling av AD/HD. IS-1244. 2005, revidert 2007. Oslo: Sosial- og helsedirektoratet, 2007.

3. Berg A, Bråtane $\mathrm{E}, \mathrm{Odland} \mathrm{HH}$ et al. Kardiovaskulær riskovurdering ved bruk av AD/HD-medikamenter hos barn. Tidsskr Nor Legeforen 2014; 134: 710-4.

4. Westover AN, Halm EA. Do prescription stimulants increase the risk of adverse cardiovascular events? A systematic review. BMC Cardiovasc Disord 2012: 12: 41

5. Winterstein AG, Gerhard T, Kubilis P et al. Cardiovascular safety of central nervous system stimulants in children and adolescents: population based cohort study. BMJ 2012; 345: e4627.

6. Mahle WT Hebson C Strieper MJ. Electrocardiographic screening in children with attention-deficit hyperactivity disorder. Am J Cardiol 2009; 104: 1296-9.

7. Graham J, Banaschewski T, Buitelaar J et al. European guidelines on managing adverse effects of medication for ADHD. Eur Child Adolesc Psychiatry 2011; 20: $17-37$ 